Vidyodaya J., of Sci., (1992) Vol. 4, No. 1,pp: 191 - 199

\title{
EFFECTS OF FOLIAR APPLICATION OF NITROGEN AND MOLYB- DENUM ON THE UPTAKE OF NITROGEN, SEED YIELD AND ITS QUALITY OF SOYBEANS (Glycine max (L.) Merr.)
}

\author{
S. S. Ranaweera \\ Department of Botany, \\ University of Sri Jayewardenepura, \\ Nugegoda, Sri Lanka.
}

Received on : $26-8-1992$

Accepted on : $10-3-1993$

\begin{abstract}
Effects of foliar nutrition of soybeans (cv.PB-I) with nitrogen and molybdenum on the seed yield and its quality are reported. Nitrogen uptake was positively affected by the foliar application of nitrogen. Foliar applcation of $1 \%$ ammonium nitrate solution (30kgN/ha) during the early pod-fill period has significantly increased the seed yield and the \% protein in seeds. This effect was further enhanced by incorporation of $0.05 \%$ ammonium molybdate in the spray solution. Application of nitrogen: $3.0 \mathrm{kgN} / \mathrm{ha}$ at two leaves $\left(\mathrm{V}_{2} 2\right)$, $15 \mathrm{kgN} / \mathrm{ha}$ at early flowering (R1-R2) and $30 \mathrm{kgN} / \mathrm{ha}$ at early pod-fill (R4-R5) periods had a better effect on the seed yield and the \% protein in seeds. The highest seed yield (1727 kg/ha), protein yield (703.4 kg/ha) and fats $(351.6$ $\mathrm{kg} / \mathrm{ha}$ ) were recorded in the fertilizer treatment where nitrogen was applied together with molybdenum at all three stages of growth.
\end{abstract}

Key words: Foliar nutrition, Nitrogen, Molybdenum, Leaf nitrogen, Seed yield, Protein and Fat content

\section{Introduction}

Nitrogen requirement of soybeans is one of the highest of agronomic crops (Sinclair and de Wit, 1975). However, nitrogen fertilization of this crop is not a common practice as combined nitrogen tends to depress the extent of symbiotic nitrogen-fixation by root nodules (Harper, 1974; Johnson et al, 1975; Weber, 1966). Until the nodules become active in nitrogen fixation, there is a great demand for nitrogen, without which the soybean plant shows symptoms of nitrogen deficiency. The use of nitrogen upto $20 \mathrm{~kg}$ per hectare for soybeans as a "starter doze" has been suggested by many researchers (Hashimoto, 1971; Singh and Saxena, 1972; Chesney, 1973), which may not meet the full demand for nitrogen at early stages of vegetative growth of the crop. 
Supply of nitrogen through uptake from soil and $\mathrm{N}_{2}$-fixation usually do not meet the demand for nitrogen of the developing seeds during period of pod-fill and nitrogen is translocated to the seeds from leaves and other vegetative purts. This decrease in nitrogen level and the breakdown of proteins cause a decrease in physiological activity and ultimately leaf senecence, thus restricting the period of pod-fill (Sinclair and de Wit, 1975). The restriction of the podfill stage can limit the soybean yields and the additional supply of nitrogen at this stage could correct this. During the period of pod-fill nodules stop fixing nitrogen and roots become inactive in the uptake of nutrients (Hanway, 1975). Belikow (Belikov, 1960) using labled ${ }^{14} \mathrm{CO}_{2}$, demonstrated that during the pod-fill stage of soybeans most of the photosynthates of a particular leaf are translocated to the pod situated at the base of the same leaf. Belikov (Belikov, 1967) observed an increase of soybean yields due to application of $3 \%$ urea solution at the early pod-fill stage. Research by Garcia and Hanway (Garcia \& Hanway, 1976) demonstrated that in certain experiments soybean yields were significantly increased by foliar fertilization with $N, P, K$ and $S$ during the period of pod-fill. They have also found that the optimum rate of nutrients for foliar application during pod-fill period was $\mathrm{N}_{80}+\mathrm{P}_{8}+$ $\mathrm{K}_{24}+\mathrm{S}_{4} \mathrm{~kg} / \mathrm{ha}$. However, very limited data regarding foliar nutrition of legume crops have been reported. Besides, previous work on foliar nutrition has mainly confined to application of fertilizers during the pod-fill stage.

The studies herein were conducted to determine the effects of foliar application of nitrogen and molybdenum at different stages of plant growth on the uptake of nitrogen, seed yield and its quality of soybeans.

\section{Materials and Methods}

A field experiment with nine fertilizer treatments as described in Table 1, was conducted at the University of Sri Jayewardenepura on a Yellow podsolic soil with sandy clay-loam texture ( $\mathrm{pH}=5.1$; Total nitrogen: $0.19 \%$; Available phosphorus ( $0.1 \mathrm{~N} \mathrm{H}_{2} \mathrm{SO}_{4}$ extractable): $10 \mathrm{mgP}_{2} \mathrm{O}^{5} / 100 \mathrm{~g}$ soil). A randomized, complete block design was employed with four replications. Plot size was $3.0 \times 6 \mathrm{M}$. Soybean variety PB-I (matures in 85 days) was planted with spacing $40 \times 5 \mathrm{~cm}$. Seeds were inoculated with Rhizobium japonicum commercial preparation, "Nitrogen $S$ " before planting. 
Table 1. Rates and times of foliar application of fertilizers for soybeans

\begin{tabular}{|c|c|c|c|c|c|c|}
\hline \multirow{3}{*}{ No } & \multirow{3}{*}{\multicolumn{2}{|c|}{ Fertilizer Treatment }} & \multirow{2}{*}{\multicolumn{3}{|c|}{$\frac{\text { Rate of Foliar Application, } N \mathrm{~kg} / \mathrm{ha}}{\text { Stages of Growth }}$}} & \multirow{3}{*}{$\begin{array}{c}\text { Total Nitrogen } \\
\mathrm{kg} / \mathrm{ha}\end{array}$} \\
\hline & & & & & & \\
\hline & & & $V 2$ & $R 1-R 2$ & $R 4-R 5$ & \\
\hline 1 & \multicolumn{2}{|c|}{$P_{80} K_{100}$ (Control I) } & - & - & $-\cdots$ & - \\
\hline 2 & \multicolumn{2}{|c|}{$\begin{array}{lll}P_{80} & K_{100} & N_{20} \\
\text { (Control I ) }\end{array}$} & - & - & - & - \\
\hline 3 & \multicolumn{2}{|c|}{$\mathrm{CII}+\mathrm{NFI}$} & 3.0 & - & - & 3.0 \\
\hline 4 & \multicolumn{2}{|c|}{$\mathrm{CII}+\mathrm{NF2}$} & - & 15.0 & - & 15.0 \\
\hline 5 & \multicolumn{2}{|c|}{$\mathrm{CII}+\mathrm{NF3}$} & 3.0 & - & $15.0+15.0$ & 30.0 \\
\hline 6 & \multicolumn{2}{|c|}{$\mathrm{CII}+(\mathrm{NF} 1+\mathrm{NF} 2)$} & 3.0 & 15.0 & - & 18.0 \\
\hline 7 & \multicolumn{2}{|c|}{$\mathrm{CII}+(\mathrm{NF} 1+\mathrm{NF} 2+\mathrm{NF} 3)$} & 3.0 & 15.0 & $150 .+15.0$ & 48.0 \\
\hline 8 & \multicolumn{2}{|c|}{$\mathrm{CII}+(\mathrm{NF} 3)+\mathrm{MoF}$} & - & - & $15.0+15.0$ & 30.0 \\
\hline \multirow[t]{2}{*}{0} & \multicolumn{3}{|c|}{$\mathrm{CII}+(\mathrm{NF} 1+\mathrm{NF} 2+\mathrm{NF} 3)+\mathrm{MoF} 3.0$} & 15.0 & $15.0+15.0$ & 48.0 \\
\hline & \multicolumn{6}{|c|}{$\begin{array}{l}\mathrm{NF}_{1}-0.5 \% \mathrm{NH}_{4} \mathrm{NO}_{3} ; \mathrm{NF}_{2} \& \mathrm{NF}_{3}-1 \% \mathrm{NH}_{4} \mathrm{NO}_{3} \text { solution. } \mathrm{All} \text { solutions for } \\
\text { sprays contained } 0.1 \% \text { Tween } 80 ;(\mathrm{M} 0 \mathrm{~F}) \text { was applied as } 0.05 \% \text { Ammonium } \\
\text { molybdate in } \mathrm{NH}_{4} \mathrm{NO}_{3} \text { solution. }\end{array}$} \\
\hline $\begin{array}{l}\text { V2 } \\
\text { R1 } \\
\text { R2 }\end{array}$ & $\bar{Z}$ & \multirow{2}{*}{\multicolumn{5}{|c|}{$\begin{array}{l}\text { Completely unrolled leaf at the unifolliolate node. } \\
\text { One flower at any node. } \\
\text { Flower at node immediately below the uppermost node with completely unrolled } \\
\text { leaf. } \\
\text { Pod } 2 \mathrm{~cm} \text {. long at one of the four uppermost nodes with a completely unrolled } \\
\text { leaf. } \\
\text { Beans begin to develop at one of the four uppermost nodes with a completely }\end{array}$}} \\
\hline $\begin{array}{l}\text { R4 } \\
\text { R5 }\end{array}$ & - & & & & & \\
\hline
\end{tabular}

All treatments in the experiment were supplied with a basal application of $\mathrm{N}_{20} \mathrm{P}_{30} \mathrm{~K}_{100} \mathrm{~kg} / \mathrm{ha}$, except for the Control-I which was given only $\mathbf{P}_{80} \mathrm{~K}_{100}$ $\mathrm{Kg} / \mathrm{ha}$. Urea, Triple superphosphate and Muriate of potash were used fur basal application. Fertilizer was brodcast and forked in. Foliar sprays with fertilizers (ammonium nitrate and ammonium molybdate) were conducted at different stages of growth (Fehr et al.,1971) as described in Table 1. The spray solution also contained $0.1 \%$ Tween 80 as a surfactant which has been previously used by other researchers (Vasilas et al.,1980). Foliar applications were made in the evening with a hand sprayer. The plots were watered with a garden flower can.

For chemical analysis plant samples were taken from each plot after five days of final spray of fertilizers applied at each stage of growth. All samples were dried to a constant weight at $70^{\circ} \mathrm{C}$ and ground. Total nitrogen of plant samples was determined by micro-Kjeldahl procedure and the samples were digested with concentrated sulphuric acid and perchloric acid as the catalyst in ratio $10: 1$ (Ranaweera, 1975) 
Plants were harvested by cutting at ground level and seeds were separated by threashing. Moisture content of seeds was determined and yields were adjusted to $13.5 \%$ moisture. Percentage of crude protein in seeds were determined by the nitrogen content $(\mathrm{N} \% \mathrm{x} 6.25)$ in seeds. Fat content of seeds was determined by defatting the ground seed sample ( $1 \mathrm{gm})$ with petroleum ether, by refluxing in a soxhlet apparatus for 18 hours (Petereburski, 1968).

Data were analysed by ANOVA method at $5 \%$ level of significance using MINITAB statistical package.

\section{Results}

\section{Uptake of Nitrogen:}

Foliar application of nitrogen and molybdenum had a significant effect on the nitrogen uptake by the soyabean plant (Table 2 and 3). Application of NFI (3.0kgN/ha) at "two leaves" stage (V2), significantly increased the nitrogen content in the plant by $0.52 \%$. Average recovery of foliarly applied nitrogen at this stage was found to be $27.6 \%$. No significant effect of molybdenum on the nitrogen ccntent was observed at V2 stage.

Nitrogen uptake was not significantly affected by the application of nitrogen (NF2) at the rate of $15 \mathrm{kgN} / \mathrm{ha}$, during early flowering (R1-R2) period. However, a combined effect of NF1 and NF2 has been observed. Application of (NF1+NF2) has increased the leaf nitrogen from $2.57 \%$ (in control II) to $3.47 \%$. Recovery of nitrogen due to fertilizer treatment, (NF1+NF2) was found to be $72 \%$ whilst it is only $44.5 \%$ due to the treatment NF2. Application of molybdenum together with nitrogen (NF1+NF2) significantly increased the nitrogen content in leaves from $2.98 \%$ to $3.41 \%$ and in stems from $0.63 \%$ to $0.84 \%$.

Foliar application of nitrogen (NF3) at the rate of $30 \mathrm{kgN} / \mathrm{ha}$, during the period of pod-fill (R4-R5) has increased the nitrogen content in pods from $3.18 \%$ in the control (II) to $3.91 \%$. Application of foliar nitrogen (NF1+NF2+ NF3) at all three stages of growth has increased the nitrogen content in pods by $0.85 \%$ and incorporation of molybdenum $(0.05 \%)$ into this treatment further enhanced the uptake upto $1.34 \%$. Total uptake of nitrogen was increased from $57.67 \mathrm{Kg} / \mathrm{ha}$ in control (II) to $69.6 \mathrm{~kg} / \mathrm{ha}$ and $75.97 \mathrm{~kg} / \mathrm{ha}$ due to NF3 and (NF1+NF2 +NF3) respectively. Recovery of foliarly applied nitrogen during the period of pod-fill was more marked $(61 \%)$ in the treatment $(\mathrm{NF} 1+\mathrm{NF} 2+\mathrm{NF} 3)$ than that in NF3 $(40 \%)$. A higher recovery percentage of $70.4 \%$ was obtained when molybdenum was applied together with (NF1+ $\mathrm{NF} 2+\mathrm{NF} 3$ ). 
Table 2. Effects of foliar application of nitrogen and molybdenum on the nitrogen content (\%) in soybean plant at different stages of growth.

\begin{tabular}{|c|c|c|c|c|c|c|c|c|}
\hline & \multirow{3}{*}{ Fertilizer Treatment } & \multicolumn{7}{|c|}{ Stages of Growth } \\
\hline & & \multirow{2}{*}{$\begin{array}{l}V 2 \\
\text { Whole plant }\end{array}$} & \multicolumn{2}{|c|}{$R 1-R 2$} & \multicolumn{3}{|c|}{$R 4-R 5$} & \multirow{2}{*}{$\begin{array}{c}\text { Harvest } \\
\text { Seeds }\end{array}$} \\
\hline & & & Leaves & Stems & Leaves & Stems & Pods & \\
\hline 1 & $\mathrm{P}_{80} \quad \mathbf{K}_{100} \quad$ (Control I) & 2.91 & 1.81 & 0.55 & 1.64 & 0.56 & 3.01 & 5.09 \\
\hline 2 & $\begin{array}{lll}\mathrm{P}_{80} & \mathrm{~K}_{100} & \mathrm{~N}_{20} \\
\text { (Control II) }\end{array}$ & 3.33 & 2.57 & 0.58 & 2.24 & 0.58 & 3.18 & 5.40 \\
\hline 3 & $\mathrm{C} \mathbf{I}+\mathrm{NF} \mathbf{1}$ & 3.98 & 2.68 & 0.57 & 2.32 & 0.75 & 3.87 & 5.44 \\
\hline 4 & $\mathrm{CI}+\mathrm{NF} 2$ & 3.68 & 2.92 & 0.57 & 2.45 & 0.63 & 3.69 & 5.69 \\
\hline 5 & $\mathrm{Cll}+\mathrm{NF3}$ & 3.68 & 2.65 & 0.67 & 2.43 & 0.98 & 3.91 & 5.91 \\
\hline 6 & $\mathrm{Cll}+(\mathrm{NF} 1+\mathrm{NF} 2)$ & 4.03 & 2.98 & 0.62 & 2.35 & 0.78 & 3.64 & 5.64 \\
\hline 7 & $\mathrm{CII}+(\mathrm{NF} 1+\mathrm{NF} 2+\mathrm{NF} 3)$ & 4.26 & 3.56 & 0.65 & 2.30 & 0.74 & 4.03 & 6.02 \\
\hline 8 & $\mathrm{ClI}+(\mathrm{NF} 3)+\mathrm{MoF}$ & 3,50 & 2.28 & 0.63 & 2.25 & 0.90 & 3.93 & 5.93 \\
\hline \multirow[t]{2}{*}{9} & $\mathrm{CII}+(\mathrm{NF} 1+\mathrm{NF} 2+\mathrm{NF} 3)+\mathrm{MoF}$ & 4.32 & 3.41 & 0.84 & 2.57 & 1.02 & 4.52 & 6.52 \\
\hline & LSD at $5 \%$ & 0.37 & 0.51 & 0.16 & NS & 0.26 & 0.49 & 0.43 \\
\hline
\end{tabular}


Table 3. Effects of foliar application of nitrogen and molybdenum, on the total uptake of nitrogen, and the recovery percentage.

\begin{tabular}{|c|c|c|c|c|c|c|c|c|c|c|c|c|}
\hline \multirow{4}{*}{$\begin{array}{c}\text { Fertilizer } \\
\text { Treatments }\end{array}$} & \multicolumn{12}{|c|}{ Stages of Growth } \\
\hline & \multicolumn{3}{|c|}{$V 2$} & \multicolumn{3}{|c|}{$R 1-R 2$} & \multicolumn{6}{|c|}{$R 4-R 5$} \\
\hline & \multirow{2}{*}{$\begin{array}{c}\text { Foliar } \\
\text { Nizrogen } \\
\text { Doze } \\
k g / h a\end{array}$} & \multirow{2}{*}{$\begin{array}{c}\text { Total } \\
\text { Uptake } \\
\text { Nkg/ha }\end{array}$} & \multirow{2}{*}{$\begin{array}{c}\text { Recovery } \\
\%\end{array}$} & \multirow{2}{*}{$\begin{array}{c}\text { Foliar } \\
\text { Nitrogen } \\
\text { Doze } \\
\mathrm{kg} / \mathrm{ha} \\
\end{array}$} & \multirow{2}{*}{$\begin{array}{l}\text { Total } \\
\text { Uptake } \\
\text { Nkg/ha }\end{array}$} & \multirow{2}{*}{$\begin{array}{c}\text { Recovery } \\
\%\end{array}$} & \multirow{2}{*}{$\begin{array}{c}\text { Foliar } \\
\text { Nitrogen } \\
\text { Doze } \\
\text { kg/ha }\end{array}$} & \multicolumn{4}{|c|}{ Total Uptake, $N \mathrm{~kg} / \mathrm{ha}$} & \multirow[b]{2}{*}{$\begin{array}{c}\text { Recovery } \\
\%\end{array}$} \\
\hline & & & & & & & & Pods & Leaves & Stems & \begin{tabular}{|c}
$\begin{array}{c}\text { Whole } \\
\text { Plant }\end{array}$ \\
\end{tabular} & \\
\hline $1 \mathrm{P}_{80} \mathrm{~K}_{100}$ (Control $\left.\mathrm{I}\right)$ & - & 2.60 & - & - & .16 .32 & - & - & 26.27 & 5.58 & 1.07 & 32.92 & - \\
\hline $2 \mathrm{P}_{80} \mathrm{~K}_{100} \mathrm{~N}_{20}$ (Control II) & - & 4.12 & - & - & 26.26 & - & - & 42.70 & 13.05 & 1.92 & 57.67 & - \\
\hline $3 \mathrm{CII}+\mathrm{NF1}$ & 3.0 & 4.98 & 28.7 & - & 31.97 & - & - & 44.95 & 14.33 & 2.50 & 61.78 & - \\
\hline $4 \mathrm{CII}+\mathrm{NF} 2$ & - & 4.56 & - & 15.0 & 32.92 & 44.5 & - & 46.87 & 11.98 & 1.80 & 60.65 & - \\
\hline $5 \mathrm{CII}+\mathrm{NF} 3$ & - & 4.15 & - & - & 28.33 & - & 30.0 & 54.68 & 12.37 & 2.55 & 69.60 & 40.0 \\
\hline $6 \mathrm{CII}+(\mathrm{NF} 1+\mathrm{NF} 2)$ & 3.0 & 4.97 & 28.3 & 15.0 & 36.87 & 70.8 & - & 45.73 & 15.78 & 2.79 & 64.30 & - \\
\hline $7 \mathrm{CII}+(\mathrm{NF} 1+\mathrm{NF} 2+\mathrm{NF} 3)$ & 3.0 & 4.89 & 25.7 & 15.0 & 39.05 & 72.0 & 30.0 & 52.09 & 21.29 & 2.59 & 75.97 & 61.0 \\
\hline $8 \mathrm{CII}+\mathrm{NF} 3)+\mathrm{MoF}$ & - & 4.56 & - & - & 24.43 & - & 30.0 & 53.15 & 14.49 & 3.00 & 70.64 & 43.2 \\
\hline $9 \mathrm{CII}+(\mathrm{NF} 1+\mathrm{NF} 2+\mathrm{NF} 3)+\mathrm{MoF}$ & 3.0 & 5.03 & 30.3 & 15.0 & 38.08 & 78.9 & 30.0 & 53.63 & 22.05 & 3.10 & 78.78 & 70.36 \\
\hline
\end{tabular}


Seed Yield and its components:

Table 4. Effects of foliar application of nitrogen and molybdenum on the seed yield, $\%$ protein and $\%$ fat in seeds of soyabeans.

\begin{tabular}{|c|c|c|c|c|c|c|}
\hline & \multirow[t]{2}{*}{ Fertilizer Treatment } & \multirow{2}{*}{$\begin{array}{c}\text { Seed Yield } \\
\mathrm{kg} / \mathrm{ha}\end{array}$} & \multirow{2}{*}{$\underset{\%}{\text { Protein }}$} & \multirow{2}{*}{$\underset{\%}{F a t s}$} & \multicolumn{2}{|c|}{ Yield, $\mathrm{kg} / \mathrm{ha}$} \\
\hline & & & & & Protein & Fats \\
\hline 1 & $\mathbf{P}_{80} \mathrm{~K}_{100}$ (Control 1) & 838 & 31.81 & 22.55 & 266.8 & 189.0 \\
\hline 2 & $P_{80} K_{100} N_{20}$ (Control I) & 1188 & 33.75 & 23.08 & 400.6 & 274.2 \\
\hline 3 & $\mathrm{CII}+\mathrm{NF1}$ & 1200 & 34.00 & 22.09 & 408.0 & 265.0 \\
\hline 4 & $\mathrm{CII}+\mathrm{NF} 2$ & 1228 & 35.57 & 23.38 & 436.8 & 287.0 \\
\hline 5 & $\mathrm{CII}+\mathrm{NF} 3$ & 1445 & 36.94 & 21.04 & 534.0 & 304.0 \\
\hline 6 & $\mathrm{CII}+(\mathrm{NF} 1+\mathrm{NF} 2)$ & 1419 & 35.25 & 2067 & 500.5 & 293.0 \\
\hline 7 & $\mathrm{ClI}+(\mathrm{NF} 1+\mathrm{NF} 2+\mathrm{NF} 3)$ & 1629 & 37.63 & 21.42 & 613.3 & 349.0 \\
\hline 8 & $\mathrm{CII}+(\mathrm{NF} 3)+\mathrm{MoF}$ & 1537 & 37.06 & 21.17 & 569.6 & 325.4 \\
\hline \multirow[t]{2}{*}{9} & $\mathrm{CII}+(\mathrm{NF} 1+\mathrm{NF} 2+\mathrm{NF} 3)+\mathrm{MoF}$ & 1727 & 40.75 & 20.36 & 703.4 & 351.6 \\
\hline & LSD at $5 \%$ & 181 & 2.68 & 1.11 & - & - \\
\hline
\end{tabular}

Foliar application of nitrogen had a significant effect on the seed yield (Table 4). Application of NF3 significantly increased the seed yield from $1118 \mathrm{~kg} / \mathrm{ha}$ in control (II) to $1445 \mathrm{~kg} / \mathrm{ha}$. Application of nitrogen at all three stages of growth $(\mathrm{NF} 1+\mathrm{NF} 2+\mathrm{NF} 3)$ had a better effect increasing it to 16.29 $\mathrm{kg} / \mathrm{ha}$ The highest seed yield of $1727 \mathrm{~kg}$ ha was obtained $\mathrm{frcm}$ the treatment $(\mathrm{NF} 1+\mathrm{NF} 2+\mathrm{NF} 3)+\mathrm{MoF}$, where molybdenum was applied in combination with nitrogen.

Application of nitrogen foliarly at pod-fill pericd (NF3) significantly increased the protein content in seeds from $33.75 \%$ in control (II) to $36.94 \%$ (Table 4). Application of nitrogen at all three stages of growth (NF1+NF2+ NF3) gave a better effect increasing the protein content to $37.63 \%$. Applicati on of molybdenum together with nitrogen in this treatment has further increased the protein content to $40.75 \%$. The highest yield of proteins $(703.4 \mathrm{~kg} / \mathrm{ha})$ and fats $(351.6 \mathrm{~kg} / \mathrm{ha})$ was recorded in the fertilizer treatment $(\mathrm{NF} 1+\mathrm{NF} 2+$ NF3) + MoF.

\section{Discussion}

Results obtained in our study has indicated a positive effect of foliar application of nitrogen and molybdenum on the uptake of nitrogen and its meatabolism in soybeans. Recovery percentages from single applications of 
nitrogen conducted at "two leaves" (V2), early flowering (R1-R2) and early pod-fill (R4-R5) periods were $28 \%, 44.5 \%$ and $40.8 \%$ respectively. Previous studies on foliar application of nitrogen for soybeans were mainly confined to the pod-fill pericd of the plant and a recovery of $51 \%$ has been observed from its application during this period by soybean cultivar "Williams" (Vasilas et al., 1980). Better recovery of $71 \%$ and $61 \%$ were obtained in the treatments, $(\mathrm{NF} 1+\mathrm{NF} 2)$ and $(\mathrm{NF} 1+\mathrm{NF} 2 \mathrm{~N}+\mathrm{F} 3)$ respectively. The total uptake of nitrogen due to application of nitrogen at all three stages of growth $(75.97 \mathrm{~kg} / \mathrm{ha})$ is more when compared to the treatment with a single fertilizer treatment given only at R4-R4 period $(69.6 \mathrm{~kg} / \mathrm{ha})$. This positive effect of increased uptake of nitrogen, probably would have been due to the absorption of more nitrogen from soil as result of efficient functioning of root system and higher rate of nitrogen fixation by root nodules. However, no significant effect of foliar nitrogen has been observed either on the nodule number or nodule weight (Results are not presented).

A significant effect of molybdenum on the uptake of nitrogen was observed when it was combined with foliar treatments with nitrogen. Role of molybdenum in reduction of nitrate in plants (Steinberg, 1937; Nicholas, 1957) and in fixation of atmospheric nitrogen by root nodules of soybeans (Van Niel, 1935; Peive, 1971) has been reported. Molybdenum is an essential component of nitrate reductase (Notton and Hewitt, 1971; Aparicio et al., 1971) and nitrogenase enzymes (Bergersen, 1970).

Results obtained from our experiment demonstrate conclusively that seed yield of soybeans can be significantly increased by foliar application of nitrogen during all three stages of growth (V2, R1-R2 and R4-R5) rather than applying it only during early pod-fill stage R4-R5).

Protein content of seeds was significantly increased both by foliar applications of nitrogen NF3 and (NF1 + NF2 + NF3). Application of molybdenum in combination with nitrogen (NF1+NF2+NF3) has further significantly increased the crude protein content. This may probably have been due to better and efficient utilization of nitrogen by the plant. The treatment (NF1+ $\mathrm{NF} 2+\mathrm{NF} 3)+\mathrm{MoF}$ has produced the highest yield of crude protein $(703.4 \mathrm{~kg}$ / ha) and fat $(351.6 \mathrm{~kg} / \mathrm{ha})$ and this seems to be the best fertilizer treatment in the experiment.

From the results obtained in our experiment it can be concluded that foliar application of nitrogen in combination with molybdenum $(0.05 \%)$ at the rate of $3.0 \mathrm{kgN} / \mathrm{ha}$ at "two leaves" stage (V2) until the nitrogen fixation by nodules sets $\mathrm{i}^{n}, 15 \mathrm{~kg} \mathrm{~N} / \mathrm{ha}$ at early flowering (R1-R2) and $30 \mathrm{~kg} \mathrm{~N} / \mathrm{ha}$ at early pod-fill (R4-R5) periods during which the soybean plant is in big demand for nitrogen, can produce high seed yield with high protein and fat content. 


\section{References}

1. Aparicio, P.J., Cardenas, J., Zumft, W G., Ma Vega, J.,Herrera, J., Paneque, A. and Losada, M., 1971. Molybdenum and iron as constituents of the en $\angle y m e s$ of the nitrate reducing system from Chlorella. Phytochem., 10:1487.

2. Belikov, I.F., 1960 Physiologia soi i kartofelya na dalnom vostokie. Academia nauk, USSR, Moscow.

3. Belikov, I.F., 1967. Vnekornivoya podkormka soi i drugih kultur kak sposob uviliche niya belka na kormah. USSR, Moscow.

4. Bergersen, F.J. and Turner G.L., 1970. Gel filteration of nitrogenase from soybean root-nodule bacteroids. Biochem. et Biophys. Acta, 214, 1:28.

5. Chesney, H.A.D., 1973. Perfermance of soybeans in the wet tropics as affected by $\mathrm{N}$, $\mathrm{P}$ and $\mathrm{K}$. Agron. J., 65 (6):887.

6. Fehr, W.R., Caviness, C.E., Burmood, D.T. and Pennington, J.S., 1971. Stage development descriptions for soybeans. Crop Sci., 11:929-931.

7. Garcia, L.R. and Hanway, J.J., 1976. Foliar fertilization of soybeans during the seedfilling period. Agron. J., 68:653-657.

8. Hanway, J.J., 1975. Interrelated developmental and biochemical processes in the growth of soybean plants. p.5-15. In: Lowell D.Hill (ed.). Proc. World Soybean Res. Conf.. University of Illionis, Urbana, III.

9. Hashimoto, K., 1971. The significance of combined and symbiotically fixed nitrogen on soybeans at successive stages of growth. Res.Bull. Hokaido Natr. Agr. Exp. Sta. 90.

10. Harper, J. E., 1974. Soil and symbiotic N requirements for cptimum soybean production Crop Sci., 14:255-260.

11. Johnson, J.W., Welch, L.F. and Kurtz, L.T. 1975., Environmental implications of $\mathrm{N}$ fixation by soybeans. J., Environ. Qual., 4:303 - 306.

12. Nicholas, D.J.D., 1957. The function of trace metals in the nitrogen metabolism of plants. Ann. Bot., 21:84

13. Peive. Y.V., 1971. Mikroelimenti i biologichiskaya fixatsia atmosfernova azota. Temryasevskaya chiteniya, (Moscow.)31.

14. Peterburski, A.V., 1968. Determination of fat content in plants. Prakticum po agronomichiskoi chemie, 6th Edn., Moskva Isdatelstvo "Kolos".

15. Ranaweera, S.S., 1975. The yield and quality of soybean seeds as affected by phosphorus and magnesium nutrition under humid tropical and subtropical condition. Pb.D. Thesis Freindship University, Moscow. (Diss. Abstr 06.01.04-Agrochemistry).

16. Sinclair, T.R. and Wit, C.T.de., 1975. Photosynthate and $\mathrm{N}$ requirements for secd production by various crops. Science. 189: $565-567$.

17. Singh, N.P. and Saxena, M.G., 1972. Field study on fertilization of soybsans. Indian J. Agr. Sci., 42 (11).

18. Steinberg, R.A., 1937. Role of molybdenum in the utilization of ammonium and nitrates by Aspergillus niger. J. Agr. Res., 55:891.

19. Van Neil. C.B., 1935. A note on the apparent absence of Azotobacter in soils. Acrh of. Microbiol, 6:215.

20. Vasilas, B.L., Legg, J.O. and Wolf, D.C., 1980. Foliar fertilization of soybean: Absorption and translocation of 15N-labled urea. Agron. .J, 72:271-275.

21. Weber, C.R., 1956. Nodulating and non-nodulating soybean isolines. II. Response to applied $\mathrm{N}$ and modified field conditions. Agron. J., 58:46 - 49.

22. Notton, B.A. and Hewitt, E.J., 1971. Incorporation of radioactive molybdenum into to protein during nitrate reductase formation and effect of molybdenum on nitrate reductase and diaphorase activities of spinach (Spinacia oleracia L.) Pl. Cell Physiol., Tokyo 12:465 